\title{
TANGGUNG JAWAB NOTARIS PENGGANTI DALAM HAL NOTARIS YANG DIGANTI MENINGGAL DUNIA SEBELUM CUTI BERAKHIR
}

\author{
Ni Nyoman Candra Krisnayanti, Ida Ayu Putu Widiati, Ni Gusti Ketut Sri Astiti \\ Fakultas Hukum Universitas Warmadewa, Denpasar - Bali, Indonesia
}

\begin{abstract}
Abstrak
Dalam masyarkat notaris sangat berperan penting. Seorang notaris turut andil dalam suatu penegakan hukum di Indonesia. Oleh sebab itu, masyarakat sangat lega dengan adanya notaris. Salah satu profesi pejabat umum yang bisa mendapatkan hak cuti yaitu seorang notaris, akan tetapi ketika seorang notaris tersebut akan cuti, maka sebelumnya harus menunjuk seorang notaris pengganti terlebih dahulu. Apabila pada saat cuti tersebut notaris meninggal dunia, disini akan membutuhkan seorang notaris pengganti yang akan sangat penting keberadaannya untuk bisa mengisi kekosongan jabatan tersebut. Berdasarkan latar belakang tersebut, penelitian ini dilakukan dengan tujuan menguraikan bagaimana status hukum notaris pengganti dalam hal notaris yang diganti meninggal dunia sebelum cuti berakhir dan bagaimana mekanisme penyelesaian administrasi protokol notaris pengganti apabila notaris yang diganti meninggal dunia sebelum cuti berakhir. Penelitian ini didesain dengan menggunakan pendekatan penelitian hukum normatif. Hasil Penelitian ini menunjukkan bahwa status hukum notaris pengganti akan menggantikan posisi jabatan dari notaris yang cuti sementara, sakit atau bahkan meninggal dunia. Notaris pengganti akan melakukan dan menjalankan segala tugas dari notaris yang digantikan dengan sementara ataupun seterusnya. Pada saat itu notaris pengganti tidak perlu dilantik lagi berdasarkan ketentuan pasal 35 ayat 3 UUJN-P. Selain itu, dalam waktu paling tidak 60 hari sejak meninggalnya notaris yang digantikan tersebut, notaris pengganti harus menyiapkan segala protokol dan membuat berita acara penyerahan protokol, lalu semua protokol tersebut diberikan kepada notaris yang menerima protokol. Jika protokol tersebut sudah diserahkan, maka kemudian akan ditandatangani oleh seorang notaris pengganti, notaris yang menerima protokol, dan majelis pengawas daerah setempat sebagai pejabat sementara Notaris.
\end{abstract}

Kata kunci: Notaris, Notaris Pengganti, Tanggung Jawab

\begin{abstract}
In a community, the notary public is very important. A notary public contributes to law enforcement in Indonesia. Therefore, the community is very relieved by the existence of a notary public. One of the general professions that can get leave rights is a notary public, but if a notary public is about to take a leave, a substitute notary public must be appoited. If at the same time the notary passed away, a substitute notary is required who will be very important to fill the vacancy of the position. Based on this background, this study was conducted with the aim of outlining the legal status of a substitute notary public in the case of a notary public that is substituted passed away before the leave is over and describing the mechanism for completing the administration of a substitute notary protocol if the substituted notary passed away before the leave is over. This research was designed using normative legal research. The results of this study indicated that the legal status of a notary will replace the leadership position of the notary who is on temporary leave, sickness or even death. The substitute notary will carry out the tasks of the notary who is subtituted temporarily or permanently. At that time the notary does not need to be inaugurated based on the provisions of article 35 paragraph 3 UUJN-P. In addition, within not later than 60 days after the death of the replacing notary, the subtitute notary must complete all protocols and make official report on protocol handover, then all protocols are given to the notary who receives the protocol. If the protocol has been approved, it will be signed by a notary, the notary who accepts the protocol, and the regional supervisory board as a temporary official.
\end{abstract}

\section{Keywords: Notary Public, Substitute Notary Public, Responsibility}

\section{PENDAHULUAN}

Notaris merupakan seorang pejabat umum yang mempunyai kewenangan untuk pembuatan suatu akta autentik dan mempunyai hak lainnya sebagaimana dimaksud dalam suatu perundang-undangan. Masyarakat dalam melakukan aktivitasnya sebagian besar berkaitan dengan hukum dan membutuhkan 
jasa-jasa hukum dari seorang Notaris (Darus, 2017). Notaris dalam lingkungan masyarakat sudah tidak asing lagi khususnya di kota Denpasar. Notaris merupakan sebutan jabatan untuk seseorang yang telah mendapatkan pendidikan hukum yang dilisensi oleh pemerintah untuk melakukan hal-hal hukum, khususnya sebagai pembuatan bukti autentik mengenai akta yang akan dibuatnya.

Notaris merupakan pejabat publik yang memiliki tugas dan tanggung jawab yang besar dalam hal melaksanakan suatu jabatannya untuk bekerja secara profesional terhadap masyarakat tanpa memandang dari sudut manapun (Edwar, A.Rani, \& Ali, 2019). Karena tugas seorang Notaris adalah melayani masyarakat, dia tidak terbatas oleh waktu dan harus mampu bekerja kapanpun selama masyarakat masih memerlukan jasa hukumnya. Ketika seorang Notaris yang sedang sakit atau yang untuk sementara waktu tidak dapat menjalankan tugas jabatannya, notaris wajib mengajukan cuti yang merupakan hak seorang Notaris yang sebagai pejabat umum.

Cuti Notaris dapat diberikan jika seorang Notaris telah melaksanakan jabatannya selama 2 tahun, dan jika kurang dari 2 tahun, Notaris belum bisa mengambil hak cutinya tersebut. Permohonan cuti dapat diajukan satu bulan sebelum tanggal cuti dimulai. Pengajuan permohonan tergantung lamanya waktu cuti dari masing-masing Notaris. Dalam pengajuan permohonan cuti seorang Notaris harus mengikuti usulan, yaitu harus ada penunjukan seorang Notaris Pengganti untuk menggantikan dan melaksanakan tugas-tugasnya nanti. Notaris yang bersangkutan menentukan jangka waktu untuk masa cutinya dan wajib untuk menunjuk seorang Notaris Pengganti. Notaris dalam menunjuk Notaris Pengganti biasanya hanya dari kalangan karyawan yang telah bekerja sekaligus magang dalam waktu yang cukup lama dan dianggap telah mampu menggantikannya berdasarkan penilaian dari Notaris itu sendiri (Adjie, 2007).

Seorang Notaris dan Notaris Pengganti dalam melaksanakan tugasnya memiliki suatu kewajiban untuk membimbing setiap orang yang datang ke kantor untuk menuangkan apa yang akan dikehendaki oleh penghadap ke dalam suatu bentuk akta (Afifah, 2017; Manuaba, Parsa, \& Ariawan, 2018). Oleh karena itu, ketika seorang Notaris hendak melaksanakan cuti, maka Notaris harus mengangkat seorang Notaris Pengganti untuk menggantikan jabatannya selama cuti agar masyarakat tetap dapat melaksanakan perbuatan hukumnya. Notaris Pengganti merupakan seseorang yang untuk sementara waktu diangkat sebagai Notaris untuk mengganti Notaris yang sedang cuti, sakit, atau untuk sementara berhalangan menjalankan jabatannya sebagai seorang Notaris.

Dalam melaksanakan jabatannya seorang Notaris Pengganti terlebih dahulu akan dilantik oleh Menteri Hukum dan Hak Asasi Manusia Republik Indonesia yang kemudian diwakili oleh Kantor Wilayah dari setiap masing-masing daerah. Ketika Notaris Pengganti melaksanakan tugas jabatannya maka harus berpedoman pada Perundang-Undangan yang berlaku dalam hal ini perundangan mengenai Jabatan seorang Notaris sebagai pejabat umum dan perundang- undangan lain yang berkaitan agar tidak terjadi kesalahan. Notaris Pengganti dalam melaksanakan tugas jabatannya terkadang mengalami suatu hambatan-hambatan karena baru pertama kali menemui dan menangani secara langsung dalam berbagai kasus.

Dalam melaksanakan jabatannya tersebut seorang Notaris Pengganti harus berhati-hati dalam hal membuatkan akta para pihak tertentu, bersikap dan berperilaku serta menjaga kesehatannya. Kehadiran Notaris Pengganti sebagai pejabat publik adalah untuk memenuhi kebutuhan masyarakat dalam hal perlunya suatu alat bukti tertulis atas setiap perikatan yang mereka lakukan sehari-hari agar tercipta suatu kepastian hukum bagi seluruh masyarakat Indonesia nantinya.

Notaris Pengganti dapat melaksanakan apa yang sudah dikehendaki oleh para pihak dalam hal pembuatan akta untuk menjamin kepastian hukum (Erwinsyahbana \& Melinda, 2018; Flora, 2012). Pelaksanaan tugas jabatan Notaris Pengganti tidak terlepas dari hambatan-hambatan dan rintangan dalam kehidupan sehari-hari, begitupun dengan Notaris yang sedang cuti. Tatkala musibah menimpa Notaris yang sedang cuti sehingga mengakibatkan Notaris tersebut meninggal dunia. Jadi, tugas jabatannya akan dijalankan oleh seorang Notaris Pengganti sebagai Pejabat Sementara Notaris.

Dari meninggalnya Notaris yang sedang cuti tersebut, maka diperlukan Notaris yang akan sanggup menerima Protokol dari Notaris yang sudah meninggal dan Notaris Penggantinya, dengan mempertimbangkan tempat penyimpanan dari arsip dokumen Negara tersebut ditempat yang aman karena akta Notaris merupakan salah satu arsip negara.

Dari uraian pada latar belakang masalah tersebut, rumusan dalam penelitian ini adalah menguraikan bagaimana status hukum Notaris Pengganti dalam hal Notaris yang diganti meninggal 
dunia sebelum cuti berakhir dan bagaimana mekanisme penyelesaian administrasi Protokol Notaris Pengganti apabila Notaris yang diganti meninggal dunia sebelum cuti berakhir.

\section{METODE PENELITIAN}

Penelitian ini menggunakan tipe penelitian hukum normatif, yaitu dengan melaksanakan suatu pengkajian berdasarkan bahan-bahan hukum dari buku-buku atau literatur dan merupakan suatu proses untuk menemukan aturan-aturan hukum dan prinsip-prinsip hukum yang berlaku di masyarakat agar menjadi suatu acuan berprilaku nantinya (Muhammad, 2004). Sesuai dengan penelitian hukum yang digunakan yaitu normatif, maka pendekatan masalah yang digunakan adalah dasar pendekatan konseptual dan pendekatan peraturan perundang-undangan. Adapun sumber bahan hukum yang digunakan, yaitu: bahan Hukum Primer yang berupa peraturan perundang-undangan yang berkaitan dengan penulisan, bahan Hukum Sekunder yang berupa buku-buku mengenai Kenotariatan, literatur, jurnal hukum, dan hasil karya ilmiah, dan bahan Hukum Tersier yang berupa surat kabar, internet, kamus hukum, dan kamus besar Bahasa Indonesia. Bahan hukum primer dalam penulisan ini diperoleh dengan membaca dan menelaah peraturan perundang-undangan dengan teknik studi pencatatan dan studi dokumentasi, sedangkan bahan hukum sekunder adalah dengan membaca dan menelaah bahan kepustakaan yang berkaitan dengan permasalahan, seperti literatur, artikel-artikel dan jurnal hukum. Setelah bahan hukum yang dibutuhkan terkumpul, bahan hukum tersebut dianalisis dengan menggunakan teknik analisis bahan hukum argumentatif dan disajikan secara deskriptif analisis, yaitu disajikan dengan apa adanya, dianalisis serta diberikan uraian-uraian dengan penafsiran untuk selanjutnya disajikan secara umum dan sistematis.

\section{HASIL PENELITIAN DAN PEMBAHASAN Status Hukum Notaris Pengganti dalam Hal Notaris yang Diganti Meninggal Dunia sebelum Cuti berakhir}

Notaris merupakan kepanjangan tangan dari pemerintah untuk memberikan pelayanan hukum secara maksimal kepada masyarakat untuk urusan akta otentik (Simorangkir, 2013). Melalui pengambilan sumpah jabatan, maka ada tanggung jawab dan wewenang yang diberikan pemerintah kepada Notaris tersebut. Notaris juga mempunyai hak cuti. Hak cuti ini dapat diambil apabila Notaris telah menjalani suatu masa jabatan selama dua tahun. Hak ini juga dapat diambil setiap tahun atau sekaligus untuk beberapa tahun disaat melaksanakan cuti. Notaris yang bersangkutan wajib menunjuk seorang Notaris untuk menggantikannya.

Ketentuan mengenai cuti Notaris ini diatur dalam Pasal 25 sampai dengan Pasal 32 UndangUndang Jabatan Notaris, yang mana Notaris sebelum mengambil cuti tersebut memiliki kewajibankewajiban sebagai syarat yang harus terpenuhi, yaitu kewajiban seorang Notaris untuk menjalankan jabatannya selama 2 tahun berturut-turut dan secara efektif. Ketika akan mengambil cuti, maka Notaris wajib hukumnya menunjuk Notaris Pengganti untuk menggantikan tugas jabatannya dalam melayani masyarakat khususnya keterkaitan dengan hukum Kenotariatan.

Dalam menunjuk Notaris Pengganti biasanya rata-rata Notaris hanya mengambil dari kalangan karyawannya yang sudah memenuhi syarat sesuai bunyi Pasal 33 UUJN-P dan telah dianggap mampu untuk mengambil keputusan dari setiap akta yang akan dibuatnya. Notaris mengajukan permohonan sertifikat cuti terlebih dahulu sebagaimana telah disebutkan diatas. Setelah Notaris memenuhi kewajiban tersebut, maka Notaris dapat mengambil hak cutinya. Pada saat dimulainya cuti, Notaris memiliki kewajiban untuk menyerahkan Protokolnya kepada Notaris Pengganti dengan dibuatkannya berita acara Penyerahan Protokol, begitu sebaliknya dilakukan 1 (satu) hari setelah cuti berakhir.

Secara umum kesalahan dan kurangnya konsentrasi sangat mempengaruhi kualitas seseorang dalam berkerja. Oleh karena itu, Notaris dapat menggunakan hak cutinya. Dalam menjalankan suatu jabatannya, seorang Notaris dituntut untuk selalu mempunyai atau memiliki kecermatan, ketelitian, kejujuran, kehati-hatian, serta kondisi tubuh yang selalu prima. Oleh karenanya, seorang pejabat notaris yang mengajukan cuti harus patuh dan siap menunjuk penggantinya karena adanya sistem notaris pengganti dengan alasan apapun yang dalam tugasnya sebagai seorang pejabat yang sedang tidak dapat memenuhi tugasnya secara sementara (Adjie, 2009). Notaris pengganti bertanggung jawab sementara sebagai seorang notaris untuk melanjutkan tugas notaris yang sedang cuti dengan alasan cuti, sakit, dan sebagainya. 
Diberlakukannya persamaan posisi hukum antara satu notaris dengan pengganti notaris menghilangkan keraguan dengan akta yang dikeluarkan oleh notaris pengganti karena memiliki kekuatan hukum yang sama dengan akta yang dibuat oleh notaris yang sebelumnya. Akta yang telah diselesaikan dihadapan notaris pengganti mempunyai sifat autentik serta memiliki kekuatan hukum pembuktian yang sempurna.

Semua yang dilakukan oleh Notaris Pengganti dan Pejabat Sementara Notaris ini sama dengan yang dilakukan oleh Notaris. Setelah dilantik menjadi Notaris Pengganti dan/ atau Pejabat Sementara Notaris, semua kewenangan, kewajiban, dan larangan akan berpindah kepadanya. Oleh karena itu, tidak semua orang dapat dipilih atau diangkat menjadi seorang Notaris Pengganti dan/ atau Pejabat Sementara Notaris. Dengan kedudukan hukum tersebut berarti Notaris Pengganti adalah pejabat umum sebagaimana dimaksud dalam ketentuan Pasal 1868 KUHPerdata berbunyi "suatu akta otentik ialah suatu akta yang dimana bentuknya sudah ditentukan oleh undang-undang, dibuat oleh atau dihadapan pegawai umum yang berkuasa dalam bidangnya, ditempat dimana akta dibuatnya". Jadi, dapat dikatakan bahwa seorang Notaris Pengganti memiliki suatu kewenangan sebagai seorang Notaris sebagaimana berdasarkan dalam Undang-Undang Jabatan Notaris, yakni sebagai seorang pejabat umum yang diangkat untuk sementara waktu dan mempunyai kewenangan sebagai seorang Notaris.

\section{Mekanisme Penyelesaian Administrasi Protokol Notaris Pengganti apabila Notaris yang Diganti Meninggal Dunia sebelum Cuti Berakhir}

Notaris Pengganti merupakan orang yang untuk sementara menggantikan tugas atau jabatan Notaris yang cuti, sakit atau untuk sementara tidak dapat atau berhalangan untuk melaksanakan tugas jabatannya sebagai Notaris sebagaimana yang tertuang dalam Pasal 1 ayat 3 UUJN-P. Notaris Pengganti ini diangkat oleh Menteri melalui Kantor Wilayah setempat. Notaris Pengganti dalam melaksanakan kewenangan, kewajiban dan larangannya sama dengan Notaris, salah satunya berhak untuk membuat akta atas namanya sendiri sebagai Notaris Pengganti. Kewenangan Notaris Pengganti setelah Notaris yang diganti meninggal dunia antara lain karena adanya sistem notaris pengganti dengan alasan apapun yang dalam tugasnya sebagai seorang pejabat yang sedang tidak dapat memenuhi tugasnya secara sementara. Notaris pengganti merupakan yang bertanggung jawab sementara sebagai seorang notaris untuk melanjutkan tugas notaris yang sedang cuti dengan alasan cuti, sakit, dan sebagainya.

Adapun kewenangan lainnya dari Notaris yakni mengesahkan tanda tangan dan menetapkan kepastian tanggal surat di bawah tangan dengan mendaftar dalam buku khusus (legalisasi). Notaris Pengganti berhak untuk melaksanakan legalisasi yang artinya membenarkan bahwa para pihak tersebut yang tercantum dalam akta telah melakukan penandatanganan surat di bawah tangan tersebut di hadapan Notaris Pengganti. Kemudian kewenangan lainnya yaitu melakukan pengesahan kecocokan fotokopi dengan surat aslinya.

Dalam setiap jabatan ada kewenangan yang dilakukan. Oleh karenanya ada kewajiban dalam pelaksanaannya. Salah satu kewajibannya yaitu mengeluarkan grosse akta, salinan akta, atau kutipan akta berdasarkan minuta akta. Kewajiban lainnya yaitu akta yang dibuatnya harus secara langsung dibaca di depan kliennya dengan harus ada sejumlah dua orang saksi sampai empat saksi tergantung jenis akta yang dibuatnya karena setiap akta memiliki perbedan prosedur dalam hal pembuatannya. Ada yang harus disaksikan oleh dua sampai empat orang saksi pada saat penandatanganan akta tersebut dilakukan. Namun pada praktek langsungnya tidak semua akta dibacakan oleh Notaris Pengganti. Hal ini tidak sesuai dengan Pasal 16 UUJN-P karena para pihak menghendaki untuk dibacakan. akan tetapi akta tersebut juga bisa saja tidak dibacakan oleh seorang notaris dihadapan kliennya apabila dengan alasan bahwa kliennya sudah mengetahui, membaca aktanya, dan sudah paham terhadap isi dari akta tersebut selama akta tersebut tidak ada perubahan lagi.

Notaris yang saat menjalankan cuti tetapi meninggal dunia duluan, tugasnya harus digantikan oleh Notaris Pengganti sebagai Pejabat Sementara Notaris. Dengan adanya informasi dari meninggalnya Notaris tersebut, maka MPD akan segera merundingkan bersama anggotanya terkait Notaris mana yang akan sanggup menerima Protokol dari Notaris yang sudah meninggal dan Notaris Penggantinya dengan mempertimbangkan tempat penyimpanan dari arsip dokumen Negara tersebut ditempat yang aman karena akta Notaris merupakan salah satu arsip negara. Majelis Pengawas Daerah dengan berbagai pertimbangan akan menunjuk Notaris penerima Protokol. Notaris Pengganti akan 
mempersiapkan semua protokol yang akan diserahkan dan menyiapkan Berita Acara Penyerahan Protokol. Berita Acara Penyerahan Protokol di dalamnya biasannya berisi jumlah akta yang akan diserahkan.

Pejabat Sementara menyerahkan Protokol Notaris dari Notaris yang meninggal dunia kepada Majelis Pengawas Daerah paling lama dalam jangka waktu 60 hari dihitung dari tanggal Notaris yang digantikan telah meninggal dunia. Namun dalam realitanya penyerahan protokolnya tidak sesuai dengan waktu yang diberikan, bahkan bisa lebih lama. Akan tetapi ada konsekuensi dari keterlambatan penyerahan protokol Notaris dan Notaris Pengganti tersebut. Sebelum dilakukan penyerahan protokolnya, Notaris pengganti harus memastikan bahwa semua Protokol Notaris sudah lengkap. Notaris Pengganti juga harus menghitung jumlah aktanya yang kemudian dituangkan dan dibuat dalam berita acara serah terima Protokol Notaris.

Notaris Pengganti memiliki batas waktu untuk menyelesaikan semua Protokol tersebut adalah 60 hari terhitung sejak Notaris meninggal dunia. Notaris Pengganti tidak memiliki jabatan dan kewenangan lagi dalam hal pembuatan akta autentik. Notaris yang meninggal dunia pada saat menjalankan cuti akan diberhentikan dari jabatannya dengan hormat dan ahli waris/ Notaris Pengganti memberitahukan atas meninggalnya Notaris yang diganti kepada MPD baik secara manual maupun elektronik paling lama 7 hari terhitung dari Notaris meninggal dunia. Penyerahan Protokol tersebut dilaksanakan paling lama 60 hari dengan pembuatan berita acara penyerahan Protokol Notaris yang ditandatangani oleh Notaris yang menggantikan sebagai Pejabat Sementara menggantikan tugas notaris yang sedang cuti ataupun lain sebagainya, Notaris penerima Protokol Notaris, dan Ketua Majelis Pengawas Daerah.

\section{SIMPULAN DAN SARAN}

1. Simpulan

Ada beberapa simpulan yang dapat dibuat berdasarkan hasil penelitian ini, yaitu: pertama, status hukum dari Notaris Pengganti dalam hal Notaris yang diganti sudah meninggal duluan saat sedang cuti dan cuti tersebut belum berakhir, maka tugasnya sebagai pejabat umum akan diteruskan oleh Notaris Pengganti sebagai Pejabat Sementara Notaris tanpa ada pelantikan sebagai Pejabat Sementara Notaris. Kedua, Mekanisme penyelesaian administrasi Protokol Notaris Pengganti dalam hal Notaris yang diganti meninggal dunia sebelum cuti berakhir yaitu Dengan adanya informasi dari meninggalnya Notaris tersebut, maka MPD akan segera merundingkan bersama anggotanya terkait Notaris mana yang akan sanggup menerima Protokol dari Notaris yang sudah meninggal dan Notaris Penggantinya dengan mempertimbangkan tempat penyimpanan dari arsip dokumen Negara tersebut ditempat yang aman karena akta Notaris merupakan salah satu arsip negara. Majelis Pengawas Daerah dengan berbagai pertimbangan akan menunjuk Notaris penerima Protokol. Notaris Pengganti akan mempersiapkan semua protokol yang akan diserahkan dan menyiapkan Berita Acara Penyerahan Protokol. Berita Acara Penyerahan Protokol di dalamnya biasannya berisi jumlah akta yang akan diserahkan.

\section{Saran}

Berdasarkan hasil penelitian yang telah diuraikan di atas, ada beberapa saran yang perlu disampaikan kepada beberapa pihak, yaitu: pertama, untuk menjamin suatu kepastian hukum bagi Notaris Pengganti seharusnya ada pelantikan kembali dari Notaris Pengganti sebagai Pejabat Sementara Notaris. Kedua, seharusnya Majelis Pengawas Daerah ikut hadir pada saat penyerahan Protokol Notaris kepada penerima Protokol Notaris untuk mensinkronkan jumlah akta yang akan diserahkan sesuai dengan berita acara penyerahan protokol yang ditandatanganinya untuk menghindari ketidaksesuaian data yang merupakan arsip Negara.

\section{DAFTAR PUSTAKA}

Adjie, H. (2007). Hukum Notariat Indonesia, Tafsir Tematik Terhadap UU No. 30 Tahun 2004 Tentang Jabatan Notaris. Bandung: Refika Aditama.

Adjie, H. (2009). Sekilas Dunia Notaris dan PPAT di Indonesia. Bandung: Mandar Maju.

Afifah, K. (2017). Tanggung Jawab dan Perlindungan Hukum bagi Notaris secara Perdata terhadap Akta yang Dibuatnya. Lex Renaissance, 2(1), 147-161.

Darus, M. L. H. (2017). Hukum Notariat dan Tanggung Jawab Jabatan Notaris. Yogyakarta: Uii 
Press.

Edwar, A.Rani, F., \& Ali, D. (2019). Kedudukan Notaris sebagai Pejabat Umum Ditinjau dari Konsep Equality Before The Law. Jurnal Magister Hukum Udayana (Udayana Master Law Journal), $8(2), 207-219$.

Erwinsyahbana, T., \& Melinda. (2018). Kewenangan dan Tanggung Jawab Notaris Pengganti setelah Pelaksanaan Tugas dan Jabatan Berakhir. Lentera Hukum, 5(2), 305-321.

Flora, H. S. (2012). Tanggung Jawab Notaris Pengganti dalam Pembuatan Akta. Kanun Jurnal Ilmu Hukum, XIV(57), 179-199.

Manuaba, I. B. P., Parsa, I. W., \& Ariawan, I. G. K. (2018). Prinsip Kehati-hatian Notaris dalam Membuat Akta Autentik. Jurnal Ilmuah Prodi Magister Kenotariatan, 1(1), 59-74.

Muhammad, A. (2004). Hukum dan Penelitian Hukum. Bandung: Citra Aditya Bhakti.

Simorangkir, J. C. . (2013). Kamus Hukum. Jakarta: Aksara Baru. 